\title{
Death in port: the explosion of the battleship Liberté in Toulon harbour (25 September 1911)
}

Thomas Vaisset Université Le Havre Normandie, UMR 6266 IDEES (France) - Service historique de la Défense

thomas.vaisset@gmail.com

\begin{abstract}
On 25 September 1911 the battleship Liberté exploded in Toulon harbour. This tragedy is just one of the many disasters that the French fleet suffered at the end of the nineteenth and the beginning of the twentieth centuries and also represents the peak of these calamities, since it is undoubtedly the most deadly suffered by a French Navy ship in peacetime. The aim of this article is to study how the navy managed this disaster and the resulting deaths of service personnel, which were all the more traumatic because the incident happened in France's main military port and in circumstances that do not match the traditional forms of death at sea.
\end{abstract}

Key words: French Navy, disaster, mass fatalities, violence, funeral practices

\section{Introduction}

The date 25 September 1911 was scheduled to be a day of mourning for the French Navy. The funerals of the victims of the accident involving the battle cruiser Gloire were due to take place inside Toulon military port. A few days previously, the explosion of a charge bag during a training exercise had killed nine sailors and injured about ten others. The funerals were planned for the early afternoon but they were overshadowed by a new tragedy unfolding in the military port. At 5.35 a.m., a few minutes after the fanfare, several blasts were heard. Huge curls of smoke, quickly followed by great sheets of flames, were coming from the battleship Liberté anchored in the port. Patrol boats and lifeboats were immediately launched to help the injured and pick up men who were throwing themselves into the sea to get off the ship. The situation seemed to be stabilising. The worst seemed to have been avoided when the commanding officer of the Liberté sounded the call to fire stations. As a result, the vessels approached to put back on board the sailors who had left the ship, so that they could help. It was 5.53 a.m. There was a huge explosion, much more powerful than the previous ones. The shock was felt up to several kilometres away. ${ }^{1}$ The Liberté, a 15,000-ton battleship, was lifted into the air like a wisp of straw. Its bow was torn to pieces, while the central part of the hull crashed down onto the stern. 
The ship was reduced to a mass of twisted metal. The death toll was unprecedented in French naval history: 226 dead and 328 injured.

The explosion of the Liberté was all the more traumatic as it happened in peacetime, less than three weeks after the review of the fleet by President of the Republic Armand Fallières in the port of Toulon. More importantly, the incident happened in circumstances that do not match the traditional forms of death at sea, namely shipwreck and illness. ${ }^{2}$ In imaginaries and in representations, maritime disasters are associated with the vagaries of the sea, with ships driven ashore or bodies and possessions lost in raging waters. ${ }^{3}$ In the nineteenth century there were many dramatic, spectacular shipwrecks. Although the example of the Titanic immediately springs to mind, it is not really representative: loss of life occurred less on the open seas and more in the 'brown waters', that is, near the coast, because of rocks, shallows and currents. Besides, these shipwrecks involved relatively little loss of life, when the growth in shipping traffic is considered. ${ }^{4}$ The nature of disasters changed, due to modifications made to the structure of ships and the development of the materials used in shipbuilding. ${ }^{5}$ New risks emerged, the most lethal of which were linked to the partial or total destruction of a ship following an explosion, most often because of an artillery accident or unstable gunpowder. And such explosions were not rare: between 1900 and 1912, there were more than thirty in the leading navies alone, resulting in the deaths of about 700 sailors. ${ }^{6}$ In the French fleet these explosions were so common that they even caused an unprecedented spike in the mortality rate. Between 1907 and 1911 there were 8.1 deaths per 1,000 men in the French Navy, ${ }^{7}$ a damning statistic when compared with the mortality rate of the Royal Navy, which was four per thousand lower at the start of the twentieth century. ${ }^{8}$ In this respect, the year 1911 was extraordinary for the French Navy in that its mortality rate reached 11.2 per thousand, or 15.3 per thousand if only squadron personnel are included. ${ }^{9}$

As a result of these new risks, the way that people were dying at sea was changing. The remains of the victims of the disasters that the French Navy suffered at the turn of the century bear witness to these changes. Unlike the importance of the 'missing body' that Alain Cabantous has highlighted as one of the main features of death within maritime culture, dead bodies are everywhere in the explosions on ships, and the victims of the Liberté were no exception. ${ }^{10}$ These human remains called for a new approach from the maritime world that was generally used to 'drowned bodies. ${ }^{11}$ Even for navies that were aware of the havoc caused by cannon-balls or grapeshot in the modern era, a threshold had been crossed. The bodies were ripped apart, shattered and dismembered. The corpses were also scattered throughout the harbour. Finding them posed a major problem, as did identifying them, because mutilation had made them unrecognisable. Finally, this type of accident changed how injuries and the injured were treated. After an incident at sea, drowning was often the fate of the survivors. This was not necessarily the case with explosions, at least for those that happened in circumstances similar to those of the Liberté. The challenge was to treat a massive influx of victims who required the care needed in battlefield medicine because of the nature and seriousness of their wounds: burns, smoke inhalation, exposure to gas, trauma linked to the consequences of the blast and so on. 
The Liberté disaster provides an opportunity to contribute to the study of violent death at sea in the twentieth century, whether in time of peace, crisis or war. The physical experience of injuries, the circumstances of death and the treatment of corpses pose the same problems as those encountered by studies about war and the violence of war. ${ }^{12}$ The fate of the French battleship is a sort of case study of what several ships would experience during the two world wars; for example, to name just the most well-known, HMS Indefatigable and HMS Invincible on 31 May 1916 at the battle of Jutland, or HMS Hood on 24 May 1941, during the hunt for Germany's Bismarck. What sets the Liberté apart is that it exploded in the port and not on the open sea, without any enemy intervention, circumstances that enabled the injured and the bodies of the dead to be collected on a quite different scale from what happens in battle. It allows us to consider the specific characteristics of military casualties in peacetime, from a standpoint similar to that introduced by the project Soldiers out of Control: An Entangled History of Accidents in the French and German Military, 1920-1970. ${ }^{13}$ However, the sailors of the Liberté are also the victims of what Yves Lequin called 'industrial death. ${ }^{14}$ The explosion of the battleship can be likened to an industrial disaster caused by poorly controlled modern technology and inadequate safety procedures, which, in some respects, reflect the emergence of technological and industrial risk in the navy. ${ }^{15}$ The supposed dichotomy of a hybrid event, occurring in peacetime but whose physical consequences suggest a context of war, can be overridden by viewing the tragedy of the Liberté as part of the 'mass fatalities' studied by the sociologist Gaëlle Clavandier. ${ }^{16}$

The records available on the incident are as vast as they are incomplete. The archives of the naval hospitals in Toulon have many gaps, making it all the more difficult to find out about the injuries suffered by the sailors. Although the oldest records kept by the Toulon branch of the Service historique de la Défense (SHD) (Defence Historical Service) date back to the second half of the seventeenth century, there is nothing in the collection after 1905. It would seem that records were not deposited; their present condition is thus a cause for concern and raises fears that they have been partially destroyed. ${ }^{17}$ In the central navy archives, kept by the SHD at Vincennes, only a few isolated documents record injuries, generally for the administrative purpose of identifying the missing. As for articles in the press, there are certainly many of them, but they seek to make their readers grasp the scale of the tragedy by highlighting a few isolated scenes rather than describing the medical consequences. However, two sources partially make up for the gaps in the documentation. The first is the collection of statements made by the survivors of the disaster to the Commission of Enquiry into the causes of the explosion of the Liberté, whose report was published in the Journal Officiel, the French government's official gazette. ${ }^{18}$ The second is a medical account of the tragedy drawn up by Chief Medical Officer Paul Gazeau for the Archives de médecine et de pharmacie navales. ${ }^{19}$ Although very detailed, it is unfortunately the only such account. Its author also acknowledges that it is incomplete, because of the scale of the disaster, the urgent need to treat the most seriously injured and the need to deal with the corpses as quickly as possible. Likewise, the condition of most of the bodies made it difficult to reach a conclusion. For many bodies there were only fragmentary, partial and 
unrecognisable remains. The comments are therefore confined to a limited number of individuals whose bodies were preserved largely intact.

Following the events of the disaster as they unfolded, this study will consider in turn the rescue operation, the consequences of the explosion for the bodies of the victims and how the navy dealt with the corpses.

\section{The rescue operation}

As in all major disasters, the rescue operation is a key challenge for the institution responsible, since it reveals its capacity to get the situation back under control. ${ }^{20}$ In September 1911 two phases can clearly be distinguished in the operation: the first is the immediate response, spontaneous and improvised, of the ships close by; the second is the treatment of the injured and the dead according to standard procedures in the French Navy Medical Service, with the support of the naval hospitals of Sainte-Anne in Toulon and Saint-Louis in Saint-Mandrier.

At the first signs of the disaster, the senior staff of the ships anchored in the harbour sent out their boats to provide assistance to the Liberté. ${ }^{21}$ While some of the boats picked up the men who had dived into the sea, others came alongside the battleship so that doctors and nurses could get aboard. This spontaneous reaction by the captains was in line with the ethics and practice of seafarers in situations of distress, which were being enshrined in law at that time. ${ }^{22}$ However, it did not rule out a desire to protect the ship for which they were responsible. Several ships sounded action stations, in order to get their crews under cover on their own ships. Others fired up their boilers, hoping to reach the open sea as soon as possible. All the sailors feared that the Liberté would explode and some, stunned by what was happening, that all the ships in the squadron would do the same. ${ }^{23}$ These measures, disorganised and sometimes dictated by panic, nevertheless reveal that there was a risk culture among naval officers. This was based as much on a long memory of the accidents that the French fleet had suffered in recent decades as in the case of the spectacular explosion of the battleship Iéna on 12 March 1907, which caused the deaths of 118 sailors following the spontaneous combustion of the smokeless powder used as an explosive charge in the shells. ${ }^{24}$

This risk culture also dictated the behaviour of the senior officers and crew of the Liberté. During the twenty minutes between the first blast and the final explosion, several attempts were made to flood the holds in the hope of avoiding fatalities or at least reducing the loss of life as in 1875, when the armoured frigate Magenta exploded in Toulon harbour. ${ }^{25}$ To fight the fire, which seemed for a while to be dying down, there was even a call to fire stations. This safety procedure, signalled by a specific alarm, was designed to mobilise the whole crew to fight the disaster. On 25 September it had the fatal consequence of bringing back on board the Liberté the members of the crew who had dived into the sea or who had found refuge on another ship. According to the Commission of Enquiry's report, those efforts were doomed to failure. It would apparently have been better to give the order to abandon ship. From the very beginning of the tragedy, the orders to flood the magazines were made impossible by the flames that were sweeping 
through the passageways and by the release of suffocating fumes. ${ }^{26}$ In spite of this, several men, including Senior Engineer Lestin, tried to carry this out but were killed.

When the explosion happened, the boats launched to give assistance to the Liberté were destroyed by the blast or else fell victim to the hail of debris which rained down on the harbour. The rescuers paid a heavy price in the disaster. They make up a significant proportion of the eighty-three men killed and 164 injured that are recorded on ships other than the Liberté, which is nearly 45 per cent of the total number of victims. ${ }^{27}$ These casualties caught the attention of the public and contributed to heightening the tragic nature of the event. In the days following the explosion, the press emphasised the price paid by the rescuers, 'victims of their devotion'. This played a part in making these men heroes in an early twentieth-century France that valued the example set by them. ${ }^{28}$ Certain anecdotes were highlighted to represent what was interpreted as a tragedy within the tragedy. In a way that reveals a great deal about hierarchies within the navy, the press coverage differed depending on the victim's rank. Officers were systematically referred to by their names; for example, Lieutenant Besson, whose legs were crushed by shrapnel or Sub-lieutenant Gabolde, killed in a lifeboat that was taking him to board the Liberté. The petty officers and the seamen remained anonymous. So, it was 'five men' of the port authority who were drowned after their boat capsized or, similarly, the whole 'crew' of one of the boats from the Ernest Renan. ${ }^{29}$

In the general rescue operation, the boats anchored in the harbour played a key role. Unsurprisingly, those closest to the Liberté took on the most injured men: for example, the battleship Justice took 150 alone. ${ }^{30}$ The ships' sick bays were on the front line. They sorted out the victims, administered first aid and separated the dying from the living. The medical evacuation of the most seriously injured men to the Saint-Louis hospital in Saint-Mandrier happened in a second phase. The transfer was made easier by the hospital's location, as it had direct access to the sea. However, this hospital soon faced the threat of being overloaded. The decision was therefore taken to send some of the injured to the Sainte-Anne hospital in Toulon. The rescue boats came alongside in the military port, by the Quai de l'Horloge, where an emergency infirmary had been set up. About a hundred stretcher posts and about fifty beds on castors and stretchers were set up opposite the mortuary chapel that was meant to house the coffins of the victims of the Gloire accident, whose funerals were due to take place that afternoon. The survivors of one tragedy came face to face with the dead of another. By midday all the men seriously injured in the explosion had received treatment. Saint-Louis took in 120 and Sainte-Anne about $40 .^{31}$ The less seriously injured men were treated in the sick bays of various ships of the squadron. There was just one exception: a quartermaster trapped in the heap of metal that the wreck had become. For several hours, the rescuers worked to free him. To release him, they had to dislocate his left forefoot, which was caught between the armour plates of the hull. The operation, which took place in very challenging conditions for the doctor concerned, was a success. However the sailor died while he was being transferred to Saint-Mandrier, probably from a fractured skull. $^{32}$ 
The Liberté disaster presented a real challenge for the navy's hospital system. In Toulon, this system was organised to deal with illnesses relevant to a fleet in peacetime, since the health of its servicemen had become a major concern of the military institutions. ${ }^{33}$ It was vital for them to adapt as quickly as possible to respond to the massive influx of men who were suffering injuries and trauma, many of which might have been caused by front-line combat. The precautions taken by the naval prefecture of the port of Toulon reveal the fear that the medical authorities would not be able to control the situation. Less than forty-eight hours after the explosion, it asked permission to break accounting rules to enable it to buy bandages and disinfectant locally in case of urgent need. ${ }^{34}$ Similarly, it asked for trainee doctors who had just finished their exams to be kept on provisionally in Toulon's naval hospitals. Most importantly, it requested that thirty-three petty officers and seamen be sent to join the nursing staff. ${ }^{35}$ The lack of nursing personnel also led the Ministry of the Navy to accept the services of the Ladies of the Red Cross. ${ }^{36}$ This approach was in marked contrast with what had happened in 1907, when the battleship Iéna had exploded and a similar request had met with a curt, flat refusal from the minister. ${ }^{37}$ Apart from aspects to which I will return later, this difference in reaction attested to the severity of the situation at the two naval hospitals in Toulon. To avoid clogging up the medical services and to deal with the influx of injured men, the work of the staff underwent an emergency reorganisation. ${ }^{38}$ On 11 October the improvement in the condition of the patients and the first discharges, which had started the previous week, meant that the hospitals no longer needed to rely on the Ladies of the Red Cross. ${ }^{39}$ The worst of the crisis was over, but the treatment of the victims was a long-term process. Administrative documents on the purchase of prosthetics by the navy enable us to see how long the hospitalisations lasted. Some operations could not be performed until several months after the explosion. For example, a quartermaster had his left leg amputated at the end of May 1912. ${ }^{40}$ Similarly, in July 1912 two sailors were still being treated, the first for an open fracture of the tibia and the second for a broken right leg as well as a wound to the face and the scalp. ${ }^{41}$

The rescue period was a critical time for the navy, especially as it had to care for the families as well as the victims. The navy undoubtedly took greater care of the families than would normally be the case after an industrial disaster in civilian life. It made it easy for them to come to Toulon to visit their injured relatives, and then it provided financial support. ${ }^{42}$ Apart from the desire to keep up the morale of the crews, this concern also reflects the highly standardised relationship of the married couple in armed forces that regulate and control the status of wives, particularly officers' wives. ${ }^{43}$ In any event, the sheer scale of the tragedy almost overwhelmed the navy's medical services, organised as they were to deal with peacetime situations. They urgently had to adapt, both to the influx of victims and to their injuries, which were those typically seen in battlefield medicine.

\section{The injuries}

The explosion caused the deaths of 226 sailors and injured 328. It was only military personnel who fell victim to this tragedy, with the city of Toulon suffering 
only damage to property. ${ }^{44}$ For the French fleet the losses were severe: this event accounted for almost half the fatalities recorded in 1911. It is no surprise that twothirds of the victims of the tragedy were from the Liberté. At least 20 per cent of its crew died in the disaster. ${ }^{45}$ When the numbers of injured are added, the losses amount to 42 per cent of the battleship's crew. ${ }^{46}$ The survivors were taken to the depot of the naval prefecture at Toulon. The demands of the military did not give them much respite: as early as the first two weeks in October, fifty petty officers and sailors were transferred to the Jules Ferry to make up its crew and allow it to leave port. ${ }^{47}$

The doctors who worked at the scene of the disaster were struck by how easy it was to identify from which ship each one of the dead sailors came. Those who drowned were almost exclusively men sent to the aid of the Liberté, whose boats were destroyed by the explosion or sunk by debris. ${ }^{48}$ The press photographs taken shortly after the events by the Roll agency or by individuals show that the harbour was strewn with pieces of metal. ${ }^{49}$ Like shrapnel or shell fragments, they had been fired in all directions by the blast. The bodies of the victims were marked by them. They were often ripped apart, shattered and dismembered. The aftermath of this deadly hail of projectiles was a forerunner of what the ordinary French soldiers in the First World War would experience in the trenches. The force of the explosion also explains why some men were killed even though they were a long distance away. The best-documented case, widely reported by the press because of its dramatic nature, was that of an officer from the Foudre, who was killed by flying metal despite his ship being anchored three kilometres from the Liberté. ${ }^{50}$

Similarly, many human remains were scattered on the various ships at anchor in Toulon harbour. With its appetite for sensation, the press produced a host of articles about bodies that were torn to shreds or dismembered and blown into the air, as well as shapeless bits of flesh that were picked up on all the ships of the squadron. ${ }^{51}$ With a certain relish, the tale was told of the Libertés bugler, whose body was found on the battleship République 'with his hand gripping a piece of the instrument on which he was sounding the alarm. ${ }^{52}$ Chief Medical Officer Gazeau reported the statement of an officer who 'saw "a deluge of flying metal and shrapnel landing on the port side and then felt a shock and a terrific blast envelop him while all sorts of debris fell around him and he was spattered with blood and bits of brain." It was an unrecognisable body from the Liberté which had landed on the deck of the République. ${ }^{53}$ All these aspects, which were widely publicised, helped to attract the public's curiosity and emphasise the exceptional nature of the disaster.

The state of the bodies of the crew of the Liberté revealed the wide range of trauma suffered by the victims. However, there were a particularly high number of skull fractures. These ranged from simple fractures with crushing to the complete collapse of the dome of the skull, exposing the lower part, with fragments of the pericranium and the facial envelope missing part or all of the brain matter. The frequency of crushing of the facial bones that was recorded was undoubtedly linked to the blowing up of the Libertés decks when the ship exploded. The victims must have been thrown from one deck against another, causing their skulls to shatter. In addition, the nurses often commented that the same individual could 
have suffered several fatal injuries. Chief Medical Officer Gazeau gave some examples: four broken limbs with bone extremities protruding through the integument; abdomens open and sometimes eviscerated; a crushed thorax and a herniated lung; and a spine broken in several places. ${ }^{54}$

Although most of the losses suffered on the Liberté happened during the final explosion, the first victims were recorded at the very start of the tragedy. Most of them were burned or suffocated. The igniting of the smokeless powder-charge bags was the cause of a fire that engulfed the whole front part of the Liberté and spread along its passageways. The fire caused panic among the crew and several men were trampled. ${ }^{55}$ The heat given off was so fierce that it blew out the windows of the sick bay, sending smoke and flames into that area and endangering the patients lying in bed. ${ }^{56}$ Almost all the sailors who suffered burns died before the explosion. The doctors reported only one patient who died from burns among the injured who had been taken to hospital. And of the twelve patients treated for burns, only one was in a serious condition. ${ }^{57}$ However, the few surviving witness statements about the effects of the burns are particularly striking. Sub-lieutenant Mathieu reported to the Parliamentary Commission of Enquiry that he was questioned by a sailor about a burned corpse: 'The body, which was white and brown, wasn't charred and looked like a wax doll that someone was trying to melt; the arms and legs were bent symmetrically at ninety degrees to the body. ${ }^{58}$ The minutes leading up to the explosion illustrated the danger that a fire represents for a ship's crew. Although fire was not a new risk on a warship, the results of industrialisation increased the danger for several reasons: the materials used to build the ships or line the decks, some of which were excellent conductors of heat; the presence on board of highly flammable and explosive material; and the compartmentation of the armour plating, which made it difficult to move around easily and prevented fumes from escaping.

The scars of the disaster were not just physical. They were mental too. Some of the men picked up by the rescue boats were in an extreme state of prostration as they had narrowly escaped drowning. ${ }^{59}$ Psychological disorders were observed in both victims and rescuers. The navy doctor Angelo Hesnard, one of the pioneers of psychoanalysis in France, carried out examinations and then produced a study of emotional psychoneuroses that he published in the Revue de psychiatrie et de psychologie expérimentale. ${ }^{60}$ The tone of the article was symptomatic of the hybrid nature of the explosion of the battleship Liberté. It anticipated the parallels that some psychiatrists would draw during the First World War between the observation of what was then called shell-shock and industrial accidents, particularly those involving the railways. ${ }^{61}$ Hesnard compared the tragedy to the 'cataclysms' represented by the Valparaiso and Messina earthquakes of 1906 and 1908, as well as the Courrières mining disaster of 1906. But, at the same time, he used his observations to try to anticipate 'during a modern naval combat, the mental accidents caused by the turmoil and depression experienced in war at sea. ${ }^{62}$ This forward-looking scientific discourse echoed the debate that permeated the French armed forces at the start of the twentieth century about the approach to adopt towards men suffering from psychological disorders. ${ }^{63}$ It also revealed the tentative evolution that was underway in how these conditions were viewed medically. The roots of these conditions were no 
longer associated exclusively with a degenerate family history and war: violence and combat were also beginning to be considered as explanatory factors.

Unlike what happens when ships explode in battle, the circumstances of the Liberté disaster allowed many medical observations to be made, even if they were incomplete. They also presented a challenge to the navy. Accustomed to 'drowned' or 'missing' bodies, it now had to deal with a huge number of bodies, many of which were badly mutilated. They had not sunk with a wrecked ship on the open sea, nor had they been swept away by currents through the vastness of the oceans.

\section{The collection, identification and burial of the bodies}

Using the statistics available about the 226 dead sailors, it can be calculated that 95 per cent of them died at the scene of the tragedy. ${ }^{64}$ The problems that arose when it came dealing with the bodies were a direct consequence of the circumstances in which these men had died.

The first problem was counting them. In the minutes following the blast, most of the ships anchored in the harbour discovered that part of their crews was missing. However, the senior officers could not draw any conclusions from this, as the situation was very confused. In the twenty or so minutes from when the first flames appeared to the final blast, many sailors left their ships, seeking to help the victims of the Liberté. The injured men picked up by the rescue boats were often put on the nearest ship, together with the medical staff who started to treat them. As a result, the doctors rarely worked in the sick bays of their own ships. Finally, the survivors of the explosion who were thrown into the sea boarded the most easily accessible ship, and not the one on which they had embarked. All these aspects help to explain the problems faced in drawing up the first list of casualties, as well as why sometimes wildly inaccurate figures circulated.$^{65}$ It took several hours to draw up a list of the missing, as each ship's captain had to make a report of the missing. ${ }^{66}$ In spite of the uncertainty, the order for coffins placed by the navy on the day after the explosion reveals its fears about the scale of the tragedy. On 26 September, 238 coffins were purchased. ${ }^{67}$

Alongside these procedures, the search for bodies began. Some were trapped in the wreck while others, blown into the air by the blast, were scattered in the harbour. The first bodies were quickly removed from the Liberté. At midday on 25 September the total was already in the teens. The operations that had to be performed to free the bodies from the ship were harrowing for the rescuers. Sometimes they had to amputate a limb to release the body from the tangle of metal that the Liberté had become. In other cases it was just pieces of leg, arm, even a 'horribly mutilated and unrecognisable head', that were removed after considerable efforts. ${ }^{68}$ To stop the smell caused by decomposing flesh, these human remains were systematically sprayed with lime and treated so that there was no risk of infection. ${ }^{69}$ From the very beginning of the tragedy, the naval authorities believed that the wreck contained many bodies. Their intuition was soon confirmed. Three days after the explosion, while cutting through some panels that were sticking up out of the water, a rescue team found several decomposing bodies. The submerged part of the ship 
was inspected by divers, who freed the bodies as best they could to bring them to the surface. ${ }^{70}$ The bodies were then collected by a barge, on which they were washed, cleaned of the dirt that covered them and examined by a doctor. ${ }^{71}$ The search of the wreck lasted many months and the dismantling work was punctuated by macabre discoveries. The Liberté was a tomb. On 28 February 1912 five bodies were found when the starboard turret was removed. ${ }^{72}$ More than a year after the tragedy, Chief Medical Officer Gazeau estimated that there were still twenty to thirty bodies trapped in the bowels of the battleship. These would finally be removed from the wreck by divers during salvage work between 1921 and $1925 .{ }^{73}$ Although the explosion of the Liberté can be read as one of the signs that it had entered the industrial age, the navy continued to be faced with the problem of the missing, that is, the bodies that could not be found, a characteristic feature of the long history of death at sea.

Other bodies had been blown into the water when the ship exploded. The day after the tragedy, the navy set about collecting these missing bodies. Until 14 October, first by day and then also at night, two steamboats sailed around the harbour looking for them. When a body was recovered it was placed on a boat moored to the wreck of the Liberté so that it could be disinfected. ${ }^{74}$ The sea also did its work. Many bodies were washed ashore and found by chance. When this happened, the police and customs officers were called upon to deal with them. ${ }^{75}$ The bodies were then given to the navy and transferred to the Saint-Mandrier hospital, where the identification process was centralised under the supervision of an investigating police officer appointed by the permanent Naval Court. ${ }^{76}$ All the bodies and human remains were taken off at the hospital's landing stage and carried on stretchers to the lecture hall, as can be seen in several photographs. ${ }^{77}$ Each morning, those ships of the squadron that had one or more men missing, sent an officer to identify the deceased. ${ }^{78}$ Relatives were also allowed in. The local press was brimming with reports about these visits that highlighted the pain of a father or the disagreement in a family over the identity of a body. These accounts were very stereotyped. They show, for example, all the conventions of supposed feminine hypersensitivity in the face of death: young women looking for a fiancé or a brother are described as trembling, on the verge of fainting, their faces distorted by emotion. ${ }^{79}$

The state of the bodies made the identification process very difficult. The injuries suffered by the sailors at Toulon were similar to those suffered during the same period by soldiers on the battlefield. Advances in armaments were causing huge change in this area, which observers were struggling to acknowledge, particularly during the Russo-Japanese war of $1904-5 .{ }^{80}$ The force of the blast and the debris projected at high speed, ripping into flesh, meant that the bodies were rarely in one piece. There is evidence of this in the reports written when the bodies found in the wreck in the weeks following the tragedy were committed to their coffins. On 28 February 1912 three of the five bodies buried, which had been discovered during the dismantling of a turret, could not be identified because of their condition. The first was totally unrecognisable, the second had been decapitated and of the third only the torso remained. ${ }^{81}$ In 1912 the Toulon court recorded the deaths of seventytwo sailors of all ranks who were still listed as missing. ${ }^{82}$ The identification rate for 
the Liberté disaster was no more than 68 per cent. ${ }^{83}$ Considering the circumstances, which were favourable to thorough searches, and which also benefited from the direct help of the families, this figure seems relatively low. It falls in between the figure recorded in France for the first months of war in 1914, in a period of extreme confusion, and the figure for the Second World War. As such, it reflects the scale of the physical injuries suffered by the sailors. ${ }^{84}$

Gathering the bodies at Saint-Mandrier had two aims: to make it easier to identify the bodies and produce the official list of victims, and to allow the collection of the bodies and their committal to the coffins. At the same time, the medical service, which was responsible for all issues relating to the deceased, carried out the administrative procedures with the civil registry situated in Toulon. This difference between the place where the deaths were registered and the place where the bodies were preserved and put into coffins made the navy liable to prosecution. This was launched by the undertakers, who had a contract giving them a monopoly on the supply of coffins for deaths registered in Toulon; otherwise a flat-rate fee was due. ${ }^{85}$ Long and acrimonious exchanges began to determine whether the indemnity was payable. A macabre interpretation of geography and accounting was put forward by the naval prefecture at Toulon to try to avoid paying compensation that it felt was unjustified. ${ }^{86}$ This affair unfolded at the same time as another, within the authorities this time, setting against each other the state, the commune of Toulon and the navy about how the responsibility for the cost of the funerals should be divided. ${ }^{87}$

Just like the reaction to the Courrières mining disaster in 1906, the tragedy of the battleship Liberté unleashed a wave of emotion across the world. As soon as news came of the explosion, condolences flowed in from all sides. Representatives of foreign states, businesses, county and town councils, as well as a huge number of private individuals sent messages of sympathy to the Ministry of the Navy. Donations and financial support for the sailors' families poured in spontaneously. ${ }^{88}$ The country was in mourning. On 4 October 1911 the victims were given state funerals in the presence of President of the Republic Armand Fallières, the presidents of both Houses of Parliament, the president of the Council and various members of the government. In spite of the exploitation of the event by Action française (a right-wing political movement) and Charles Maurras, the funerals were a sign that tensions over the issue of secularism were gradually easing, especially when they are compared to what had happened in 1907 after the Iéna explosion. ${ }^{89}$ Although Fallières and the members of the government arranged their arrival in Toulon so that they missed the religious service led by the bishop of Fréjus in Toulon cathedral, that was the only parallel between the two events. In 1911 all the elected representatives attended the Absolution pronounced by Monseigneur Guillibert in Toulon city centre. The head of state bowed to the prelate as he greeted him, which caused comment in both the Catholic and the Republican press. ${ }^{90}$ In the same way, the clergy played a full part in the funeral procession. The easing of tension in relations between the Republic and the Church could be seen also in the issue of spiritual help for the victims, a major concern of the Catholics, which caused far less controversy than after the Iéna explosion. In 1911 the republicanisation of the navy, of which an important element was the secularism of regular service, was on the way to being concluded 
in an atmosphere of calm. ${ }^{91}$ However, it was not entirely a new chapter. Evidence of this could be seen in the port naval prefect's refusal to allow Monseigneur Guillibert to visit the sailors in hospital, or the strong reaction of the nationalist and Catholic press when there were no priests allowed at the bedsides. ${ }^{92}$ When it came to the armed forces, visiting the injured was a bone of contention in the relations between the Republic and the Church. ${ }^{93}$ It was a vital part of regaining control and asserting political power in the period after the accident. ${ }^{94}$ The Chief of General Staff of the navy, Vice-Admiral Paul Auvert, who was in Toulon for the funerals of men from the battleship Gloire that same day, was the first to go to Sainte-Anne on the morning of 25 September and Saint-Mandrier that afternoon. ${ }^{95}$ The minister of the navy, Théophile Delcassé, arrived in Toulon on 27 September and made a visit to the two naval hospitals, together with a large number of journalists who reported the event. In the same way, the funeral ceremony in honour of the sailors was organised to satisfy the wish of the President of the Republic to visit the Saint-Mandrier hospital. ${ }^{96}$

The survivors had a place of honour in the arrangement of the official ceremony on 4 October. Accompanying the victims' families, they walked in front of the coffins of their dead comrades. The hierarchy in place on board ship was respected, since the first person in the procession was the captain of the Liberté, followed by the officers, then the petty officers and sailors. This staging reflects the organicist concept of a warship prevailing in the navy. It is also a symbolic representation of the idea that a crew forms one body in life as in death. On a wider scale, it reveals the strength of the notion of hierarchy in French society at the end of the nineteenth and the start of the twentieth centuries. The funeral procession reached its destination in the military port, where the official funerals took place. After the speeches of the political and military leaders, detachments of sailors from all the ships stationed in Toulon paraded between the President of the Republic and the bodies. This procession was to some extent a reverse mirror image of the naval review that had taken place exactly one month previously in Toulon harbour, during which the head of state had hailed the 'rebirth' of the fleet. ${ }^{97}$ These official funerals were only for the dead who had been identified. Three other ceremonies were organised in October as new bodies were discovered or identified. As for those who remained unidentified, they were buried in the Souvenir français (French War Graves Commission) plot at Lagoubran cemetery in Toulon. ${ }^{98}$ They were joined by those that families had refused to collect. ${ }^{99}$

Once the official ceremony was over, the bodies that had been identified were returned to the families who had requested it. From the evening of 4 October, the first coffins left Toulon bound for Saint-Maurice, near Paris. ${ }^{100}$ The navy covered the cost of transport and the funerals. It also ensured that there was a solemn atmosphere at the funeral services. It made sure that a representative of the navy or the state attended and that military honours were paid a second time to the dead when they were interred. ${ }^{101}$ However, the generosity of the ministry was not boundless and did not extend to all funeral expenses. It excluded in practice any memorials. So, although the purchase of objects to decorate the coffins was covered by the navy budget, the same was not true for headstones. ${ }^{102}$ The navy took no steps to 
commemorate the explosion in one way or another. It let Souvenir français take on the task of erecting a monument in memory of the victims and allowed its staff to contribute only privately to the fundraising effort. ${ }^{103}$ In the same way, it was not the naval prefecture of the port of Toulon but the archpriest of Toulon who was behind the ceremony organised to mark the first anniversary of the disaster. ${ }^{104}$ As for support for the bereaved families, the widows and orphans, gaps in the sources prevent discussion of this issue.

\section{Conclusion}

Caused by the instability of smokeless powder, whose dangers were, however, already well known, the explosion of 25 September 1911 was part of a long list of tragedies that the French fleet suffered at the end of the nineteenth and the beginning of the twentieth centuries. The Liberté disaster is, moreover, the peak, not least because of the scale of the loss of life. It is undoubtedly the worst peacetime disaster suffered by a French Navy ship. Only the torpedoing of the Léon Gambetta (1915), the Amiral Charner (1916) and the Danton (1916) or the wreck of the Bouvet, struck by a mine in April 1915 in the Dardanelles, as well as the destruction of the Bretagne at Mers-el-Kebir in July 1940, would approach - and indeed exceed such a loss of life. At the same time, the two world wars brought back into sharp focus the shipwreck as the archetypal cause of death at sea, even if this cause was no longer accidental, but due to torpedoing by submarines.

The Liberté provides an example of the fate predicted on the eve of 1914 by the theoreticians of naval warfare for ships and their crews in times of war. But it is unique in that it happened in port, in peacetime - that is, in circumstances that allow us to understand the consequences for the victims, which was clearly not the case in 1905 at the battle of Tsushima. Moreover, some doctors have likened the tragedy of the Liberté to a clinical case study for describing the physical and mental effects of war at sea. In some ways, the testing ground in Toulon shows how the physical experience of violence, the circumstances of death and bereavement that affected the sailors of the early twentieth century, like how the navy dealt with the bodies, anticipate what the ordinary French soldiers would face a few years later. It reveals comparisons with industrial disasters that should be further explored. There seem to be many common features, even if the way in which the consequences of the tragedy were dealt with appears to differentiate these 'mass fatalities'.

In addition, further consideration should be given to how the explosion of the Liberté is remembered in the navy. Although it was used as a reference or a model, for example during the ceremonies organised in 1922 for the return of the bodies of the sailors killed in Athens in December 1916, the mark it has left is somewhat ambiguous. ${ }^{105}$ The victims of the 1911 tragedy died in port, in peacetime, following an avoidable accident. These features set their death in contrast with the navy's concept of a glorious death - one that is heroic and takes place in battle - which it was keen to promote, as is clear from the vain attempt to create a myth around the torpedoing of the Léon Gambetta in 1915. ${ }^{106}$ However, the event was not forgotten. Some of its participants were even honoured as part of the naming policy of the 
navy. This choice reflects the way in which the navy tried to highlight the courage of the rescuers in order to indirectly push the disaster into the background and shift the meaning of an edifying death, by stressing the idea of sacrifice. It was Engineer Lestin, killed during a desperate attempt to flood the Libertés holds and Sub-lieutenant Gabolde, cut down in a lifeboat that was taking him to board the ship, who gave their names to two of a line of destroyers launched in 1913. It is also noteworthy that the last of these destroyers was named Enseigne-Roux, in reference to an officer killed in the Iéna disaster. This also enabled the navy to reduce its responsibility for the tragedy, given that the dangers of smokeless powder were well known. The parallel with the 'heroism-screen of technological death' that was aimed at establishing courage as the main response to technological hazard is clear. ${ }^{107}$ The explosion of the Liberté brought about the immediate and definitive withdrawal of this explosive in the navy. Just as in civilian life, disaster sometimes leads to changes in military standards and practices. ${ }^{108}$ On this subject, two avenues would lead to further study. The first would be to publish the exchanges and sharing of knowledge between the major navies that had faced similar accidents, especially through their naval attachés. The second would consist in determining the 'learning from experience' from the disaster and its consequences, particularly when it came to regulations concerning the treatment of bodies in wartime and the training of the sailors assigned to the squadrons.

\section{Notes}

Translated by Cadenza Academic Translations.

1 R. Daveluy, Réminiscences (Paris, Economica, 1991), p. 470.

2 P. Masson, La mort et le les marins (Grenoble, Glénat, 1995).

3 F. Walter, Catastrophes. Une histoire culturelle XVIe-XXIe siècle (Paris, Seuil, 2008), pp. $172-6$.

4 A. Cabantous and G. Buti, De Charybde en Scylla. Risques, périls et fortunes de mer du XVIe siècle à nos jours (Paris, Belin, 2018), pp. 138-40.

5 P. Louvier, 'Les maladies et les accidents dans la marine de guerre française en Méditerranée au XIXe siècle (1815-1914)', Corps, 15:1 (2017), 305-14.

6 Service historique de la Défense, archives of the French Navy kept at Vincennes (henceforth SHD-MV), BB7 160, note from the General Staff, 18 December 1912.

7 P. Niaussat, 'La Marine française face à la pathologie et à lépidémiologie pendant la Première Guerre mondiale', in C. Buchet (ed.), L'homme la santé et la mer (Paris, Honoré Champion, 1997), p. 421.

8 P. Niaussat, 'Les santés à l'épreuve', in Marine \& technique au XIXe siècle (Vincennes, Service historique de la Marine et Institut d'histoire des conflits contemporains, 1988), p. 543.

9 Statistique médicale de la Marine pendant l’année 1911 (Paris, Imprimerie nationale, 1915), pp. 70-1.

10 A. Cabantous, 'Le corps introuvable. Mort et culture maritime (XVIe-XIXe siècles)', Histoire, Économie \& Société, 9:3 (1990), 321-36. 
11 F. Chauvaud (ed.), Corps submergés, corps engloutis. Une histoire des noyés et de la noyade de l'Antiquité à nos jours (Paris, Créaphis, 2007).

12 On the topic of death and injury, see L. Capdevila and D. Voldman, Nos morts. Les sociétés occidentales face aux tués de la guerre (XIXe-XXe siècles) (Paris, Payot, 2002); A. Rasmussen, 'Blessures et blessés', in B. Cabanes (ed.), Une histoire de la guerre: Du XIXe à nos jours (Paris, Seuil, 2018), pp. 438-52. More generally, see $\mathrm{W}$. Bruyère-Ostells, 'Bilan historiographique et limites de l'approche purement historienne de la violence de guerre au XIXe siècle', Corps, 15:1 (2017), 249-59.

13 Soldiers out of Control: An Entangled History of Accidents in the French and German Military, 1920-1970, joint research group project between the Institut d'Études Avancées de l'université de Strasbourg (USIAS) (University of Strasbourg Institute of Advanced Studies) and the Freiburg Institute for Advanced Studies (FRIAS, Universität Freiburg), led by Anne Rasmussen and Peter Itzen.

14 Y. Lequin, 'La mort industrielle', in J. Delumeau and Y. Lequin (eds), Les malheurs du temps. Histoire des fléaux et des calamités en France (Paris, Larousse, 1987), pp. 477-94.

15 J.-B. Fressoz, L'Apocalypse joyeuse. Une histoire du risque technologique (Paris, Seuil), 2012; T. Le Roux, 'Lémergence du risque industriel (France, Grande-Bretagne XVIIIe-XIXe siècle)', Le Mouvement Social, 249:4 (2014), 3-20.

16 G. Clavandier, La mort collective: Pour une sociologie des catastrophes (Paris, CNRS Éditions, 2004).

17 My thanks go to the curator of the Toulon branch of the Service historique de la Défense (Defence Historical Service) for this information.

18 Journal officiel de la République française, 'Rapport de la commission nommée par le vice-amiral commandant en chef la 2e escadre pour rechercher les causes de l'explosion de la Liberté, appendix to the 24 October 1911 issue. This document will henceforth be referred to the Commission denquete (Commission of Enquiry).

19 H. Gazeau, 'Relation médicale de l'explosion de la Liberté, Archives de médecine et pharmacie navales, 99 (1913), 5-36.

20 Clavandier, La mort collective, pp. 66-80.

21 Collectively, these boats are known as a military ship's drome in French. They can be either on the ship itself or docked in port.

22 On 23 September 1910 the international convention for the 'unification of certain rules on maritime assistance and rescue' ended in Brussels. For more on the history of this topic, see P. Louvier, 'Projection d'influence: l'action humanitaire de la marine française au XIXe siècle', Stratégique, 114:1 (2017), 45-66.

23 A. Hesnard, 'Les troubles nerveux et psychiques consécutifs aux catastrophes navales', Revue de psychiatrie et de psychologie expérimentale, 18:4 (1914), 142.

24 Other examples include the explosions of the armoured frigate Magenta in 1875, the gunpowder magazine at Lagoubran in 1899, those that took place in 1906, 1907 and 1908 on board the battleship La Couronne and that of a turret of the battle cruiser Latouche-Tréville in 1909. In addition to these are the disappearance of the transporter ship Vienne (1903), the shipwrecks of the submarines Farfadet (1905) and Lutin (1906), as well as the groundings of the battle cruisers Sully (1905), Jean-Bart and Chanzy (both 1907). 


\section{Thomas Vaisset}

25 M. Guérout and J.-P. Laporte, Le Magenta. Du naufrage à la redécouverte (1875-1995) (Paris, CNRS Éditions, 2018).

26 Commission d'enquête, p. 1566.

27 Statistique médicale de la Marine, p. 72.

28 La République du Var, 26 September 1911. See also F. Caille, La figure du sauveteur. Naissance du citoyen secoureur en France (Rennes, Presses universitaires de Rennes, 2006).

29 Le Figaro, 26 September 1911.

30 SHD-MV, BB4 2447, list of the names of the injured from the battleship Liberté, n.d.

31 Service historique de la Défense, archives de la Marine conservées à Toulon (Defence Historical Service, navy archives kept at Toulon) (henceforth SHD-MT), 1F2 2, letter no. 400 from Chief Doctor Ambiel, director of the medical service, to the vice-admiral, naval prefect of the port of Toulon, 18 October 1911.

32 La République du Var, 26 September 1911, and Gazeau, 'Relation médicale', 22.

33 See, for example, the special issue entitled 'La santé des soldats entre guerre et paix, 1830-1930', edited by J.-F. Chanet, C. Fredj and A. Rasmussen, Le Mouvement social, 257:4 (2016).

34 SHD-MT, 2A3 589, telegram no. 2525 from the naval prefecture of the port of Toulon to Marine Paris, 27 September 1911.

35 Ibid.

36 SHD-MT, 1F1 112, directive from the minister of the navy to the vice-admiral, naval prefect of the port of Toulon, 28 September 1911.

37 J. de Préneuf, Mentalités et comportements religieux des officiers de marine sous la Troisième République, Ph.D. dissertation, Université Paris X-Nanterre, 2007, pp. 600-1.

38 SDH-MT, 1F1 2, letter no. 456 from Chief Doctor Ambiel, director of the medical service, to the admiral of the port of Toulon, 25 November 1911.

39 SHD-MT, 1F2 2, note no. 391 from Chief Doctor Ambiel, director of the medical service, to the admiral of the port of Toulon, 9 October 1911.

40 SHD-MT, 1F2 3, letter no. 218 from Chief Doctor Ambiel, director of the medical service, to the admiral of the port of Toulon, 20 May 1912.

41 SHD-MT, 1F2 3, on the condition of those most seriously wounded in the explosion of the Liberté, as established by Chief Doctor Ambiel, 3 July 1912; SHD-MT, 1F1 113, directive from the minister of the navy to the vice-admiral, naval prefect of the port of Toulon, 6 June 1912.

42 SDH-MT, 1 F1 112, directive from the minister of the navy to the naval prefect of the port of Toulon, 28 September 1911.

43 W. Serman, Les officiers français dans la nation (1848-1914) (Paris, Aubier, 1982), pp. 145-83; on the situation in the police, see M. Bergère, 'Épouser un gendarme ou épouser la gendarmerie? Les femmes de gendarmes entre contrôle matrimonial et contrôle social', Clio. Femmes, Genre, Histoire, 20 (2004), 123-34.

44 SHD-MT, 2 A3 589, letter no. 1415, from the Service central des travaux hydrauliques (Central Service for Hydraulic Engineering) to the naval prefect of the port of Toulon, 27 November 1911. 
45 Statistique médicale de la Marine, p. 72.

46 Gazeau, 'Relation médicale', 18.

47 SHD-MV, BB3 1326, telegram no. 2713 from the naval prefecture of the port of Toulon to Marine Paris, 5 October 1911.

48 Gazeau, 'Relation médicale', 25.

49 Bibliothèque nationale de France (French National Library) (henceforth BNF), department of prints and photography, Roll, 17145; SHD-MV, $231 \mathrm{GG}^{2} 1$, photographic plates 37-55 and 56-75; SHD-MV 245 GG $^{2} 3$, photographs nos. 20 and 21.

50 This story was reported for example by Le Petit Journal on 26 September 1911 and by La Croix on 27 September 1911.

51 Examples include articles printed in the 26 September editions of the following daily newspapers: Le Petit Var, Le Petit Marseillais, La Petite République and L'Ouest-Éclair.

52 Le Figaro, 26 September 1911.

53 Gazeau, 'Relation médicale', 12-13.

54 Ibid., 26.

55 Statement from auxiliary fireman Vinciguerra (Commission d'enquête, p. 1588).

56 Witness statement from certified fireman Porchat (ibid., p. 1597).

57 Gazeau, 'Relation médicale', 28.

58 Witness statement from first ensign gunner Mathieu (Commission denquête, p. 1580).

59 Gazeau, 'Relation médicale', 27.

60 M. Turbiaux, 'Un psychiatre-psychanalyste à l'ombre des épées. Angelo Hesnard (1886-1969), médecin de la Marine, neuro-psychiatre, psychologue, hygiéniste, Bulletin de psychologie, 504:6 (2009), 553-68.

61 L. Crocq, Les traumatismes psychiques de guerre (Paris, Odile Jacob, 1999), pp. 223-4.

62 Hesnard, 'Les troubles nerveux et psychiques', p. 141.

63 M. Derrien, 'Éliminer ou récupérer? Larmée française face aux fous du début du XXe siècle à la Grande Guerre', Le Mouvement Social, 253:4 (2015), $13-29$.

64 Percentage calculated using Statistique médicale de la Marine, p. 72.

65 SHD-MV, BB3 1332, telegram no. 83151 from the admiral in charge of the Patrie to Marine Paris, 27 September 1911.

66 SHD-MV, BB8 2014, report of the missing signed by Captain Fatou, captain of the battle cruiser Léon Gambetta, 27 September 1911.

67 Le Petit Var, 27 September 1911.

68 Le Petit Var, 28 September 1911.

69 Gazeau, 'Relation médicale', p. 23.

70 SHD-MV, $245 \mathrm{GG}^{2}$ 3, photograph no. 26.

71 Gazeau, 'Relation médicale', 23.

72 SHD-MV, BB8 2014, telegram no. 5883 from the naval prefecture of the port of Toulon to Marine Paris, 28 February 1912.

73 Le Matin, 7 May 1922. 


\section{Thomas Vaisset}

74 SHD-MT, 1F3 2, order nos. 221 bis and 234 from the General Staff to the naval prefecture of the port of Toulon, 26 September and 13 October 1911.

75 Europeana collections, 2024913_Ag_EU_EuropeanPhotography_Parisiene_1007.

76 SHD-MT, 2A5 79, order no. 1034 from the naval prefect of the port of Toulon, 26 September 1911.

77 BNF, department of prints and photography, Roll. 17194.

78 SHD-MT, 1F3 2, order no. 1037 from vice-admiral Marin-Darbel, 26 September 1911.

79 See for example Le Petit Var, 24 September 1911.

80 O. Cosson, Préparer la Grande Guerre. L’armée française et la guerre russo-japonaise (1899-1914) (Paris, Les Indes Savantes, 2013).

81 SHD-MV, BB8 2014, report of the 5th company of the Maritime Gendarmerie on the burial of five bodies from the wreckage of the Liberté, of which only two could be identified, 28 February 1912.

82 SHD-MV, BB8 2014, letter no. 1569 from the public prosecutor at the Court of Appeal in Aix to the minister of the navy, 21 May 1912.

83 Calculation made using SHD-MT, 1F2 3, report on the number of victims of the Liberté disaster, by the commanding officer of the 5th company of the Maritime Gendarmerie, 16 January 1912.

84 Capdevila and Voldman, Nos morts, p. 53.

85 SHD-MT, 2 A3 589, letter no. 2447 from the naval prefect of the port of Toulon to the minister of the navy, 21 December 1911.

86 SHD-MT, 1F1 113, telegram from the minister of the navy to the naval prefect of the port of Toulon, 1 February 1912.

87 SHD-MT, 2 A7 287, letter no. 629, from the minister of the naval prefecture of the port of Toulon to the mayor of Toulon, 5 April 1911.

88 Documents about this are kept both at Vincennes (SHD-MV, BB8 1800 et BB7 155) and Toulon (SHD-MT 2A7 286 et 2A7 287).

89 Préneuf, Mentalités et comportements religieux, pp. 632-5.

90 See, for example, the 4 October 1911 editions of the daily socialist republican newspaper Le Petit Var and of La Croix. On the contrary, the edition of L'Humanité published on the same day does not mention this event.

91 J. de Préneuf, 'La politique de républicanisation de la Marine à la Belle époque', Revue d'histoire maritime, 14:2 (2011), 29-60.

92 L'Action française, 30 September 1911 and La Croix, 1 October 1911.

93 X. Boniface, L'Armée, l'Église et la République (1870-1914) (Paris, Nouveau monde éditions, 2012).

94 Clavandier, La mort collective, pp. 66-80.

95 SHD-MT, 2 A3 589, telegram no. 2479, from Vice-Admiral Auvert to Marine Paris, 26 September 1911.

96 SHD-MV, BB2 937, telegram no. 3378, from the minister of the navy to the naval prefect of the port of Toulon, 28 September 1911.

97 Le Petit Journal, 4 September 1911.

98 SHD-MT, 1F3 2, order no. 1069 from the naval prefecture of the port of Toulon, 4 October 1911. 
99 SHD-MT, 1F2 2, letter no. 402 from Chief Doctor Ambiel, director of the medical service, to the vice-admiral, naval prefect of the port of Toulon, 19 October 1911.

100 SHD-MT, 2A3 589, telegram no. 2693 from the naval prefecture of the port of Toulon to Marine Paris, 5 October 1911.

101 SHD-MT, $1 F 1112$, directive from the minister of the navy to the naval prefects of all naval arrondissements, 28 September 1911.

102 Ibid.

103 SHD-MT, 4A3 36, decision no. 383 of the naval prefect of the port of Toulon, 3 April 1912. Topped with a cross, this monument in Lagoubran cemetery is adorned with plaques providing details about the explosion and explaining that the grave that lies beneath it contains the remains of the sailors who could not be identified.

104 SHD-MT, 1F3 3, communication no. 1098 of the naval prefect of the port of Toulon, 21 September 1911.

105 SHD-MT, 2F4 12, message no. 1008 from the naval prefect of the port of Toulon to the minister of the navy, 12 July 1912.

106 M. Perry, 'Vive la France! Death at Sea, the French Navy and the Great War', French History, 26:3 (2012), 344-66; J.-B. Bruneau, 'La marine française dans la Grande Guerre à l'épreuve de la littérature', Revue d'histoire maritime, 20 (2015), 157-75.

107 F. Caille, 'L'héroïsme-écran de la mort technologique. La célébration du courage civil dans l'accident industriel ou productif au XIXe siècle', in T. Le Roux (ed.), Risques industriels. Savoirs, régulations, politiques d’assistance fin XVIIe-début XXe siècle (Rennes, Presses universitaires de Rennes, 2016), pp. 227-54.

108 One of the most famous counter-examples of this is the explosion of the gunpowder factory at Grenelle in 1794. See T. Le Roux, 'Accidents industriels et régulation des risques: l'explosion de la poudrerie de Grenelle en 1794', Revue d'histoire moderne et contemporaine, 58:3 (2011), 34-62. 